\title{
The Atlantic Prehistory of Private International Law: Trading Companies of the New World and the Pursuit of Restitution in England and France, 1613-1643.
}

\begin{abstract}
This article concerns itself with the kind of legal conflicts that broke out in the Atlantic New World between merchant interests from different European loci. Case studies are made of two disputes: one between Samuel Argall of the Virginia Company and a factor on behalf of Antoinette de Pons at the Île des Monts-Déserts, and the other between the Compagnie de Caën and the Kirke brothers on the St Lawrence River. Together, these case studies reveal how important it was for merchant interests to have resident ambassadors and state officials advancing their interests in England and France. Procedural difficulties and jurisdictional uncertainty often impeded the road to redress, it is shown. Additionally, this article suggests that the peacetime reckoning of events associated with warfare provided an optimal opportunity for disaffected private actors to have their claims for redress recognised. The extent to which private overtures for restitution relied upon public acts of diplomacy reveals some of the reasons why it is not possible to date the origins of private international law before the long nineteenth century. Rather we might profitably identify, in events such as these, the prehistory of private international law.
\end{abstract}

A striking characteristic of European activity in the seventeenth-century New World was the greater involvement and agency of trading companies. While some of these companies were rogue agglomerates of traders, most others were officially endorsed entities, ranging in size from the intimate syndicates of local entrepôt merchants to the much larger, monopolistic, joint-stock corporations. It has been for a long time well understood that companies of this kind played an important role in the foundation of early modern empires. Historical research in just the last decade has begun to yield more nuanced appraisals of the East India companies in particular and their relationships both with founding imperial polities and also with nonEuropean communities, following the pioneering interventions of Philip J. Stern in The Company-State. ${ }^{1}$ What appears to be less understood, and more especially so in the Atlantic context, are some of the demands that the relationships between companies of different European origin abroad made upon the existing legal and political institutions of Europe. When companies infringed upon the rights of each other in highly contested and sometimes judicially unsophisticated parts of the extra-European world, what means of redress, if any, were available to the disaffected interests back in Europe? An enquiry of this type must necessarily pay some deference to Lauren Benton, whose research into the comparative history of jurisdictional politics and legal pluralism in the extra-European world has yielded a number of remarkable findings for historians of early modern imperialism. ${ }^{2}$ This approach has recently culminated in A Search for Sovereignty (2010). Revealing how a variety of legal conflicts, generally perceived to be of a criminal nature, allowed for the opportunistic construction of sovereignty by Europeans abroad, Benton identifies some of the geographical variations between different 'corridors' and 'enclaves' of law. ${ }^{3}$ This article, by contrast, will be concerned with colonial contexts where spaces of this kind were yet to be carved out of the ports, coastlines, and townships of the seventeenth-century New World. Here trading companies were neck and neck, falling often into dispute with one another.

In the New World, private actors from different European backgrounds made little recourse to indigenous systems of arbitration, as they typically believed themselves to be operating in areas deficient of the judicial institutions capable of resolving their conflicts. This was especially the 
case concerning the unbiased acknowledgement of trespass in disputed foreign territories and liability for non-contractual wrongs generally in private law (what was firming into tort in the English legal tradition, and délit civil in the French), in the absence of which there could be no pursuit of restitution for damages. There was no court in colonial America, for instance, that could oblige French traders to observe English jurisdiction, just as there was no court in colonial America that could oblige English traders to observe French jurisdiction. Even if there were courts of this kind, there could be no guarantee of the impartiality of their adjudications. And there was little that Europeans could bring with them into the New World to extricate themselves from this condition of jurisdictional deficit, making exception only for 'letters of marque and reprisal', which were not easy to come by. Documents of this kind had been issued throughout the Middle Ages to facilitate restitution for subjects from whom property had been unjustly seized beyond their own realm and were therefore in the absence of normal recourse. Upon receiving letters of marque from their own local authorities, aggrieved subjects could then collaborate for the purpose of seeking the restoration of their property or the equivalent compensation. ${ }^{4}$ Importantly, wherever these documents allowed for the restitution of property, this provision was only applicable to moveable property. Essentially, these letters provided a public endorsement of a particular private law interest abroad, and in that sense, had to be taken seriously by foreign recipients during the latter Middle Ages, lest their actions attract even greater attention from foreign war-making sovereigns. From the fifteenth century onwards, the political audacity of these documents ensured that they were typically used only in contexts of open war, or contexts in which provocative restitution was expected to bring about the declaration of open war or reprisals in return. Letters of marque and reprisal therefore represented an exceptional, unreliable, and controversial means of seeking redress in the seventeenth-century New World. Less functional still for this kind of purpose was a colonial charter, regardless of the delusions sometimes held by those who carried one into the New World and irrespective of the ceremonialism superficially attached to it. Charters, commissions, donationsbrev, lettres, octrooien, patents, and other legal instruments of the same kind were specific to particular jurisdictions and particular subjects, and none were capable of imposing any kind of obligation upon foreign Christians. In continuity with medieval tradition, sovereign donations of property and jurisdiction affected only those subjects loyal to the same sovereign and could not lawfully impinge upon the liberties of others. ${ }^{5}$ On their own, charters could not transplant judicial mechanisms into foreign territories capable of mediating between individuals from different political and legal backgrounds. In sum, then, trading companies operating so far away from their founding jurisdictions were easily stalemated when they fell into conflict with one another, regardless of the prestige and privilege of receiving official sanction in domestic and metropolitan political settings.

In Europe, sovereigns personally showed some ambivalence towards the foreign affairs of trading companies. While it was not uncommon for kings and queens to take up the cudgels for individual subjects during the earliest stages of the 'age of discovery', a slight move away from this approach can be detected in the early seventeenth century first of all in England, where James I/VI dissociated himself from all responsibility over the actions of the London and Plymouth Companies almost immediately after their incorporation by his seals. Complain as the Spaniards did vehemently in a number of European courts about the Virginia project throughout 1609, during a time of formal peace between England and Spain, the official line in response was that 'his Majesty pleads that the undertaking is a private one and that he cannot interfere', as the Venetian ambassador to England conveyed at the time. ${ }^{6}$ In the period between 1600 and 1670 - between the first significant challenges levelled against Iberian overseas supremacy by France, England, and the United Dutch Provinces, and the definitive adoption by those states of the political economy of mercantilism - private legal interests were cast 
abroad into foreign waters and increasingly dissociated from those of their public sovereigns. More and more, instead, it was left up to stationed diplomats to advocate on behalf of their merchant countrymen, doing so generally in the language of Roman law. As a result, the purview of renaissance diplomacy expanded to take in diverse issues of a private law nature, additional to those specific matters of public law originally under its mandate. This marks a significant transformation from the types of duties traditionally associated with resident ambassadors. ${ }^{7}$ Increasingly, an officially stationed representative appeared not just for his sovereign, but for certain subjects of his sovereign too. He did so by furnishing depositions from abroad for use in local courts, by advocating for his fellow subjects imprisoned for debts and defaults, and by negotiating with royal, noble, and merchant interests in commercial matters. His successes were mixed.

This article seeks to contribute to our understandings of diplomacy, imperialism, and private law in this window by focusing in particular upon conflicts associated with the New World. Regardless of the persistence of ambassadorial advocates on behalf of private interests in this new moment, efforts to secure reparations for damaged private interests were constrained, firstly, by the insufficiency of established judicatures in Europe and, secondly, by the fitfulness of public warfare across the continent, as this article will explain. It was never obvious to statesmen, jurists, and least of all merchants, how private legal disputes of an international nature could be brought to courts unused to hearing them, all while the select community of European nations arbitrated their own differences through chaotic and often spontaneous battles fought increasingly far away from their own set patriae. What emerges from the archives is a most confusing legal context which can be characterised neither by singularity nor by fixity. This is a finding that runs contrary to the implication, unintended though it might be, of those arguments which hold that a fluid and complex state of legal pluralism was a distinctive feature of the frontiers and coastlines of the colonial world. Rather, it will be proposed here that the politics of jurisdiction in the history of early modern imperialism were just as significant in the Old World as they were in the New World.

What were the procedural and jurisdictional difficulties raised by conflicts between foreign merchants before the development of state-centric mercantilism? And how did the changing circumstances of war and peace influence the options available to disaffected private interests of this kind? Focusing on the relationships between English and French trading companies in the North American New World, this article proceeds to answer these questions by recounting two separate disputes and following them through to their dissipations.

The first part of the article considers the destruction and despoliation of several French settlements on the North Atlantic coastline by Samuel Argall of the Virginia Company. Throughout 1614, members of the French syndicate behind these settlements appealed to the crown, and from there a claim for damages was passed onto the Privy Council via the French ambassador in London. This was different to most other extra-European legal conflicts, and all of those concerning the continent, because the property at stake was both moveable and immoveable. Here, in other words, land as much as things was up for grabs in international law - and as ever, the distinctions between public and private were to be blurred in pursuit of restitution. The Virginia Company responded to French demands in a statement that is well known to historians. At the risk of making too much of the overtly loyalist language adopted by all English chartered companies during this period (and for some time after it), this extraordinary document can be shown to represent a bold declaration of the extent of English royal authority over the New World. ${ }^{8}$ On the other hand, it seems probably more appropriate in the context of this dispute to regard the document as an expression of the London entity's 
corporate privileges and responsibilities, and from that starting point, proceed to consider the points of law which had to be overcome in order to escape a private obligation of restitution. Escape from this obligation the company did in the end, helped more so by the reluctance of the Privy Council to offer a ruling on the matter than anything else.

The second part of the article considers the capture of Québec and the confiscation of inventories belonging to the Compagnie de Caën and the Compagnie de la Nouvelle-France during two raids by the Kirke brothers for themselves, their backers, and their family trading company. Justifying their behaviour by holding up obscure letters of marque, the Kirkes committed their first depredations in 1628, during a time of public war, and their second depredations in 1629, as hostilities were ceasing. While much has been made of the resolve of ambassadorial representatives for both crowns in the negotiations leading up to the restoration of Québec and Acadia, much less has been made of the separate issues of private law involved. ${ }^{9}$ Records of negotiation at Susa and Saint-Germain-en-Laye during the organisation of a working peace after the Anglo-French War allow historians to piece together only one side of the story. Another side of the story can be presented by balancing out the flummoxed opinions of ambassadors, solicitors, and judges, heard in the ill-equipped courts of England and France, as they were confronted to repair the individual interests damaged during the events of 16289. These matters represented more difficult questions than the public negotiations which kept diplomats busy, and they took longer to resolve, principally because of the incapacities, at the time, of existing legal institutions on both sides of the Channel.

\section{THE VIRGINIA COMPANY OF LONDON AND THE MARQUISE OF GUERCHEVILLE}

The Virginia Company of London was first chartered in 1606 alongside the Virginia Company of Plymouth. They were to be neighbours - Plymouth to the north up to the Bay of Fundy and London to the south down to Cape Fear - until the Plymouth corporation became defunct and the London corporation received new charters for itself in 1609 and $1612 .{ }^{10}$ Despite assuming the right to operate in the northern component of the grant, the Virginia Company of London would retain its original focus on the southern component of the grant. Here, Jamestown became the principal locus of settlement, wracked intermittently, though it was, with famine throughout this period. So dire was the need for victuals that the Virginia Company became accustomed to trading its precious commodities for corn and cod up north, following the success of an expedition led by Samuel Argall in 1612. ${ }^{11}$

French interest along the St. Lawrence River predated both Virginia projects, although permanent sites of settlement would not be established by small trading companies until 1603 at Tadoussac, and 1608 at Québec, and 1610 at Port-Royal. Indeed, 'Nouvelle-France' was always something of a revolving door. ${ }^{12}$ Partially this was due to the steady trickle of lettres and commissions from kings to jostling sieurs - a trend which began during the reign of Henri IV (1589-1610) and would not abate until the accession of Cardinal Richelieu to premier ministre in $1624 .{ }^{13}$ In the middle of this window, René le Coq de la Saussaye agreed to lead a small expedition across the Atlantic to found a new settlement, 'Saint-Sauveur'. Confirming his participation, he entered into a contract in August of 1612 with his sponsoring syndicate, comprised of Jean de Biencourt de Poutrincourt and Antoinette de Pons, the Marquise of Guercheville. ${ }^{14}$ After winter in early 1613, La Saussaye along with a small crew and a modest Jesuit entourage left Le Havre in the Jonas for the Île des Monts-Déserts, the projected site of Saint-Sauveur. 
It was in this very springtime window that Argall and a crew of sixty men were dispatched on another food-finding mission for the Virginia Company, edging northwards along the American coast in the Adventure. They would go no further north than the Penobscot River, for here Argall spied the Jonas along with a smaller pinnace docked near Saint-Sauveur at the very earliest stages of its fortification. The French under La Saussaye had been settling in for little more than a month before Argall made his advance in July. The Englishmen stormed the Jonas, and quickly moved to take control of Mount Desert Island, slaying three Frenchmen who resisted their approach and causing the flight into the woods of many others. It cannot be known with any certainty who it was that fired the first shot in this affray, but the record is unanimous about the rapidity of the French submission to Argall. Surrender was very quick. ${ }^{15}$

Mayhem followed. Sheepishly La Saussaye boarded the Jonas, overrun by Englishmen, to beg wherefore. Argall explained that he found their settlement within the limits of Virginia as declared in the Virginia charters, and prompted La Saussaye to prove what right he had to establish a settlement here. To this, La Saussaye claimed his authority came from his French king, so he should be treated 'not as a robber, but upon an equal footing'. His proof of this, La Saussaye assured Argall, was the commission locked away in the chest on the Jonas. In front of Argall and his crew, together with those of the French who surrendered (including Maitre Charles Fleury of the Jonas, and the Jesuit Father Biard from whose relation this story principally derives), La Saussaye removed the keys from his pocket and opened the chest to reveal 'everything else untouched and in its proper place, but no commission'. ${ }^{16}$ When the mist settled on this farcical scene, Argall saw red. Offended at the blatancy of this French affront to the Virginia Company of London, he made the equation that the French were 'forbans \& pirates' under the authority of nobody special, which led him to the radical conclusion that their booty was therefore claimable for Virginia. He took whatever salt and fishing equipment he could and piled it into the Adventure; La Saussaye and some of his crew were crammed onto a meagre fishing boat and pushed in the direction of France; Biard, Fleury, and the rest were carried back to Jamestown as captives on the Adventure, which was trailed by the latest addition to the company's fleet, the Jonas. ${ }^{17}$

Upon his return to Jamestown, Argall was promptly ordered by the council to head north before the imminent arrival of winter not only to loot from the remaining French but also to destroy all signs of French occupation. Evidently it was more concerning that the French were fortifying settlements on land than it was that they were habitually fishing just off the coast. Argall outfitted the Jonas and the Capitanesse, and appointing the captive Frenchmen as his guides, He made again for Saint-Sauveur, reaching the Île des Monts-Déserts in October just as he left it. Here he ordered what remained of Saint-Sauveur to be dismantled, destroying also the French markers at the site. Next, Argall and his fleet moved to the abandoned settlement of Île Sainte-Croix. Here he did the same. Finally, Argall reached Port-Royal, which was somewhat different to the other sites. ${ }^{18}$ Allegedly, this was Poutrincourt's personal settlement. Here the land was divided into strips and granted to farming censitaires 'habituated to the country', Rameau tells us, 'and determined to stay', under the management of Poutrincourt's son, Charles de Biencourt. ${ }^{19}$ But, for whatever reason, neither Biencourt nor any of Pourtincourt's censitaires were around to defend the settlement at the time of Argall's arrival in November of 1613. The settlement appeared, instead, to lie vacant, except for some livestock, which Argall either destroyed or led onto the ships. Likewise, after taking whatever of the grain and vegetables that would keep fresh, Argall and his men then destroyed the fields of crops. Finally Argall ordered all the buildings in the young colony to be razed. Leaving PortRoyal reaped of its natural bounties and burning in flames, Argall and his fleet pulled out of the port with his loot and made a course home for Jamestown. ${ }^{20}$ But they did not sail far before 
a fateful storm gathered overhead and erupted to disperse the fleet. Argall in the Capitanesse was diverted towards Manhattan Island. After a comical run-in with the Dutch he found there, Argall pulled out of the Hudson River and made southward for Virginia, which it reached sometime in December. ${ }^{21}$ The suffering Jonas in the meantime embarked upon a more trying journey. By heavy winds the vessel was blown far into the Atlantic. Among its passengers were Father Biard and a few other French captives, who became desperate for fresh food and water until necessities were finally provided for at Azores. From there, the Jonas aimed for England. $^{22}$

When news of the French losses reached France in October of 1613, the outcry was instant. The old and venerated constable of France, Henri de Montmorency, 'in the name of France', and on behalf of the Marquise de Guercheville, who was 'particularly interested in this loss', promptly made three requests directly to King James:

one, that you will command that the two Jesuit Fathers be returned in safety with the other prisoners; the other, that the restitution be made [for this] remarkable plundering ['volerie'], which cost the said Dame more than a hundred thousand livres of loss; and the third, that your Council or Société of Virginia will declare and explicate where they intend to set the boundaries and confines of the said country of Virginia. ${ }^{23}$

Signing off on his letter of solicitude for the Madame de Pons, Montmorency insisted to the English king that the Sieur de Bisseaux, Samuel Spifames, be kept informed of his response. This was sensible. As the French Ambassador to England, Spifames was ideally situated to pick up the mantle (and, indeed, the ongoing correspondence which Spifames instigated with the French foreign minister, the Marquis de Sillery Pierre Brûlart, on the topic, suggests that he took more than a passing interest in the affair while based in London). That Argall was 'not a pirate without commission', but an 'employee of the company established to traffic into Virginia', gave the incident an intriguing character in Spifames's appraisal, over and above the fact that Argall's actions on the Île des Monts-Deserts were 'not only illegally contrary to the bond of amity between two nations bound by confederations and treaties, but also contrary to the law of nations'. ${ }^{24}$ His opinion was no different when the battered Jonas pulled into Pembroke some moths later carrying news of the destruction of Port-Royal, prompting Spifames to redouble his efforts on the matter of restitution. In May of 1614, the ambassador sent a message to Brûlart calling for more pressure to be applied from Louis XIII on the question of 'Port Royal, ancient discovery of the French, and in their possession for more than sixty years before the English were cognisant of Virginia, which [the English] entirely demolished, ravishing its produce and other commodities belonging to the poor French'. The damages inflicted not just upon the Jonas but upon the entire settlement demanded restitution to his diplomatic mind (but then again, so did a great many things, of which the catch of the day in the Greenland seas was only slightly the bigger concern of his in this period). ${ }^{25}$

The French complaints addressed to King James about the Jonas were diverted to the Privy Council in February, which was not an unusual destination for petitions adverting to the absence of ordinary justice. By the early Stuart period, the Privy Council - typically comprised of about twenty or so members, including the secretary of state, and sometimes the king himself - had developed a mediative and investigative jurisdiction over a wide range of 'weightie matters of the Realme', both private and public. ${ }^{26}$ Just as the Privy Council often went out of its way to protect English merchant interests at home and abroad, so in return it was equally prepared to receive petitions concerning foreign interests, and to arbitrate if only to give the appearance of justice. ${ }^{27}$ And this is indeed how the Privy Council looked to intervene early in 
the case of the Marquise, by their resolution to summon Argall 'for restitution and punishment', upon his return into England when more information on the affray would arrive to hand. ${ }^{28}$

A month or so later, additional pressure on the case came from an unlikely source in the form of La Saussaye himself, who was sent to London personally to rehearse the complaints of his employer, De Pons, about the Jonas and her alleged out-of-pocket loss of 100,000 livres. ${ }^{29}$ This figure, which is consistent with the amount originally declared on her behalf by Montmorency the previous October and equated to somewhere near $£ 10,000$ sterling, is difficult to fathom without some appreciation of the interests that were personally involved in the dispute. In 1603, Henri IV granted the rights of seigneurie and monopoly in Canada to Pierre du Gua de Monts. De Monts had been a regular visitor to the Saint-Laurent in the 1590s, and was backed by a company of merchants from separate situations along the western coast of France. ${ }^{30}$ He was accompanied by Samuel de Champlain and Poutrincourt on an expedition of 1604, when Port Royal caught the latter's eye. Poutrincourt requested the whole beach and vast hinterland in seigneurie as a 'don' from de Monts in August of $1604 .{ }^{31}$ A contract to this effect prepared, Poutrincourt then approached Henri IV in early 1606 to have the donation confirmed. This afforded some certainty for him, and his son Beincourt, for little more than a year, because the king soon changed his mind on the struggling De Monts's company and revoked the original privileges of $1603 .^{32}$ Poutrincourt's deed to Port-Royal was brought into question with this revocation, and was then rendered more questionable still when Henri IV died and was replaced by the interim regency of Marie de Médicis, anticipating the succession of Louis XIII. In order to realise his dreams of living large in l'Acadie, Poutrincourt was forced to find a new link to the royal court. This he found in the form of Madame de Pons, the Marquise of Guercheville, wife of the Duke of Liencourt and Governor of Paris Charles du-Plessis. De Pons was eager to dispatch Jesuit missionaries to Canada for the purpose of converting the indigenous population to Catholicism, for which reason she was a driving force behind the Compagnie de Jesus. In her religious fervour, she was nothing like Poutrincourt who, for whatever else he may have claimed in order to attract support, was primarily motivated to have the lands in and around Port-Royal preserved to his family and left in the custodianship of his son, Biencourt. ${ }^{33}$ These were the circumstances which brought Poutrincourt and De Pons into a singular concern. De Pons being a woman, her contrat d'association with Poutrincourt was only possible in the presence of her husband, with whose authority their syndicate was formed. ${ }^{34}$ From Champlain's account of this transaction - compiled on what authority it cannot be certain - De Pons was highly sceptical of the rights to land Poutrincourt claimed to possess. She demanded to see written titles, which Poutrincourt refused to show, and so insisted on the conveyance of 'all rights, actions, and claims he has or ever had in New France'. ${ }^{35}$ Neither is it clear what of these privileges were still valid in 1611 nor how much the Marquise paid for them, but the endorsement of the purchase by the Regent appears to have given some assurances that the title to all of l'Acadie (minus Poutrincourt's claim to Port-Royal) was reconstituted and seamlessly affixed to the Guercheville estate.

In this light can the demand for 100,000 livres be appreciated. If the initial capital outlay of Poutrincourt and De Pons can be approximated at 750 livres each (as La Saussaye's reconnaissance implies), and, on top of that, the burdens unique to Saint-Sauveur - namely, the costs of mustering and sending out the Jesuits, and the value of the improvements made to the settlement before its demolition - are accounted for charitably, an estimate reaches no more than a tenth of that grand figure. ${ }^{36}$ Perhaps the Jonas was expected to find gold in New France. Or, what is more likely, to be accounted for on top of this is the compensation requisite to quit the claim to the Île des Monts-Déserts. The suit's origin not with the near-bankrupted Poutrincourt, but with the noblewoman de Pons (whose contract of 1611 apparently gave her 
title of the land in question), might offer further confirmation that the amount represented a claim for the reimbursement of a failed speculative investment in real estate abroad, rather than just the value of the things damaged or carried off by Argall to Virginia, or otherwise the anticipated returns of the voyage. In that sense, the claim for 100,000 livres represented an unusually complicated demand for private restitution, which begged for jurisdiction, but for which in 1614 there was little precedent to insist upon extending.

At the beginning of June, Spifames lost no opportunity to address the new secretary of state, and former ambassador to the Hague, Sir Ralph Winwood - by happenstance also a director of the Virginia Company of London - on the matter of the Jonas. ${ }^{37}$ In Winwood's mind, the battered sloop was a relatively easy matter to decide upon. After the ship and everything in it was released sometime around the $22 \mathrm{nd}$ of June, there was nothing more to be done. ${ }^{38}$ The secretary of state was blasé in his deflection of the dame's further demands, telling Spifames that 'she has no reason to complain, nor to expect any reparation'. ${ }^{39}$ The French thought very differently. In August, Spifames instructed Maître Fleury, now safely in Rouen, to prepare a detailed report on the Saint-Sauveur incident, which was compiled and eventually passed onto the Privy Council afterwards. ${ }^{40}$ In October, Antoinette de Pons addressed Winwood personally, with the request that he 'uphold the reparation of a grand tort', using legalese which clearly confirmed - if indeed any confirmation was required by those implicated in her allegations that the matter was one of private law which demanded principled deliberation irrespective of the division between their respective civil jurisdictions. 'I promise', De Pons forebode, 'that I will be obliged to you as a result of what will come from such a just restitution'. ${ }^{41}$ Spifames too was reluctant to let the matter subside, chivvying enthusiastically for the acknowledgement of 'the particular interest of madame the marquise of Quiercheville', which, in his mind, surely 'merited recompense' after the destruction of Saint-Sauveur. ${ }^{42}$

The Virginia Company had different ideas about the matter. Sometime amid all of this, an official statement was compiled in London for the directors - maybe by Richard Martin, lawyer to the company from 1612, or perhaps it was William Crashaw, the company's learned preacher - in response to the enquiries of the Privy Council. ${ }^{43}$ Without any contradiction, the company's statement is deferential to its progenitors yet boldly declaratory of its own individual personality. The most obvious indication of this arises in the company's comprehensive assumption of responsibility for Argall's actions. For both ransacking voyages, Argall held 'severall com[m]issions' from the company, and was under the explicit 'commande of the Gov[ernor] of our Colonye, by his Comisssion to him given under the Seale of the Colonye, \& by virtue of such authoritye as is to him derived from His Ma[jesty's] Great Seale of England'. The French differences, the document's author stresses on no less than a few occasions, were not with Argall personally, and much less with the king's council, but were above all others with the Virginia Company and its 'Colonye'. From this basis, the corporation offered its rejection of the French claims. Addressing the summer ransacking of Saint-Sauveur, the company admitted to taking a 'french Shipp', but as it was 'taken between 43 and 44 Degrees', it was therefore 'within the Limitts of our Colony [...] wee haveinge granted unto us from 36 to 45 Degrees of no[rth] Latitude, \& from E. to W. from one sea to another'. When Argall discovered that the French intended to 'get Land' and 'plante contrarye to the extente and Priviledge' of the company, the Virginia council found itself forced to defer to a 'certaine Clause' of the company's royal charters which rendered it 'Lawfull for our Gov[er]nor to resist, displante, $\&$ take by force any that shoulde make such attempte'. This was untrue, of course, as none of the Virginia charters permitted aggression against foreign subjects, but it was up to the French, now, to call the bluff. In the meantime, the corporation admitted some culpability; though it played down all French allegations of Argall's 'inhumanitye', the Virginia Company 
estimated that the value of the goods stolen from Saint-Saueveur could amount to no more than $£ 200$ sterling (approximately 2,000 livres). ${ }^{44}$

The document turned next to address the subsequent ransacking of Poutrincourt's Port-Royal. Argall's conduct was lawful, the corporation found, because of the 'com[m]ission given to him under the Seale of the Colonye', which instructed him to demolish all 'reliques of any fortificac[i]on, or other markes of clayme, or Plantac[i] on to the [said] Porte'. As the settlement was found 'within 44 degrees or thereabouts, and within the Limitts, and precincte of our Colonye', it was Poutrincourt who was at fault, not the Virginia Company. Besides all of this, the settlement was entirely 'abandoned'. Argall had 'found not one' settler at Port Royal. In order, then, to perfect 'the Clayme, \& tytle of our Sayde Colonye to [tha]t Saide P[orte]', the corporation had no choice but to commission Argall, with its own seal, to remove 'all such silent $\mathrm{p}$ [re]tence \& ensig[ns] of Dominion'. These actions were right, the Virginia Company stressed, not only because the French were temporarily absent from Port-Royal, but because the French had not been physically present in northeastern America until after the formation of the first Virginia charters. The only exception to this rule which the company was prepared to make was for Québec. This was considered the only place that the French had 'any footinge' in the New World. Everywhere else, the company had come first. For that reason, the company concluded,

the Kinge of France is neither in his Hon[ours] nor tytle any waye injuryed by the Just Defence of our owne [... nor] hath Madam de Guerchevile any reason to expecte reparac[i]on havinge entered without our Leave, with[in] ou[r] Limitts and dominion, by force to plante, or trade contrarye to the good correspondence, $\&$ League of those two most royall Kings. 45

That completed the statement, which removed the corporation singularly from any obligation to repair the damaged interest of De Pons. In the process, by way of a marginal argument, it ridiculed the absentee proprietorship of Poutrincout. Its allegations were not without some glaring logical deficiencies. By referring to the privileges afforded to the company by James I of England in this defence, the Virginia Company was framing the matter as an international dispute that would have been incredibly difficult, in the period, to have arbitrated. Comparing royal paperwork across monarchies was practically impossible, and besides this, was theoretically pointless on questions of company charters, insofar as donative documents of the kind established exclusive rights and conditions to be observed only by subjects of the monarch issuing them. ${ }^{46}$ Resolving this particular dispute would have been made all the more difficult by La Saussaye's missing commission, which might not have even existed (despite the suggestions of Fleury and Biard to the contrary), as there is no proof elsewhere of its delivery. ${ }^{47}$ Accompanying the Virginia Company's fickle argument based on exclusive royal grants was the seemingly contradictory placement of the onus of physical occupation upon the French. It was not considered that this argument, which was mobilised only in application to Argall's second lots of ransackings when the Acadiens were either kept captive or temporarily absent at the time, could just as easily have counted against the Virginia Companies of London and Plymouth, neither of which had any attachment to the region in this period (regardless of the great fib delivered by Argall to Christiaenszoon the year earlier in Manhattan). There was, therefore, much audacity to the claims of English authority abroad too; whether or not the French had full enough access to the appropriate legal institutions to challenge them was another question though. 
In the end, Winwood's original assessment that De Pons had no grounds for a claim was upheld. But this was most likely due to the Privy Council declining jurisdiction over such a thorny matter than it was to any principled argument tendered by the Virginia Company. There would be no remedy for the French in England or in America. The last anything is reported of it comes just before Christmas in 1614, when Sir Thomas Edmondes, ambassador to France, told Winwood of his embarrassment for being summonsed before a royal audience in Paris where he was shamed publicly by the French queen. That De Pons 'was forced to make an extraordinary instance for the redress' of her losses was still a matter of some gravity at this stage, evidently. ${ }^{48}$ But the matter was on its way into memory. De Pons was not awarded the sum of 100,000 livres from the Virginia Company of London after diplomatic pressure on the case waned on both sides of the Channel. She was left with one option, and that was to encourage her husband to bring an action for his contract with De Monts on her behalf. That no suit of this kind ever materialised ensured that De Pons, for all her Catholic zeal, would become memorable in Canadian history only as the first of many after her to lose out in a highrisk investment in colonial land.

\section{THE BROTHERS KIRKE AND THE COMPAGNIE DE CAËN}

Europe was plunged into the Thirty Years War from 1618. A brittle alliance between England and France only disintegrated, however, after the rise of the expansionist Cardinal Richelieu to premier ministre in August of 1624 and the succession of Charles I to the English throne in March of $1625 .{ }^{49}$ Throughout 1626 and in the early months of 1627, England and France descended piecemeal into conflict following the differences of opinion between their kings over debt, dowry, and denomination. These were the triggers to a war definitively underway after the attempted English siege of Saint-Martin-de-Ré in the summertime of 1627, and fought principally off the French coast until the Treaty of Susa of April $1629 .{ }^{50}$

It was within this wartime window that the Kirke family business shifted its sights from Europe to Québec. Previously, the Kirkes had been involved in the acquisition and redistribution of wine, an enterprise entirely autochthonous to the Channel. ${ }^{51}$ By the 1620 s, Gervaise Kirke, the family patriarch, had fostered important mostly Huguenot networks at La Rochelle and Dieppe for this purpose. Following the French seizure of merchant wine vessels at Bordeaux at the beginning of 1627 , this family business, which had thrived on the dual loyalties of the Kirke family, became no longer feasible. ${ }^{52}$ With war came a new commercial opportunity for the Kirkes to engage in a 'proxy war' for Charles I. ${ }^{53}$ This was a job Gervaise left to his sons. It would be David Kirke, for his brothers, who 'obtained letters of marque' from the delegates of Charles I on December 17th, 1627, which authorised (it can only be presumed) their capture of French prizes in the Atlantic during the Anglo-French War. ${ }^{54}$

By this time, the French presence on the Saint-Laurent and in l'Acadie had grown even more conflicted than it was before. Interlopers remained the problem they always had been, but on top of this, there were separate companies claiming exclusive rights in the region too. Into this situation stepped a new monopoly, in the form of the Compagnie de la Nouvelle-France, which was freshly endorsed to consolidate French interests. Emerging from the winter of 1627/8, the first to descend upon Canada after the creation of the new company, were Samuel de Champlain and the seventy-odd inhabitants of Québec desperate for provisions from home. Fortunately, the Compagnie de la Nouvelle-France was outfitting a number of ships to be sent out to him in the new year, and most of these left Dieppe for Québec in April. Unfortunately for Champlain, however, another fleet of three ships - commanded by the French-born Kirke 
brothers - had left England for the Saint-Laurent with designs to raid the French settlements just weeks before the departure of the Compagnie's fleet.

The Kirkes were the first to reach the Saint-Laurent by some four weeks. In that time, they collected prisoners from Cap Tourmente and Tadoussac, and hijacked a handful of ships, including a number of small fishing vessels and, eventually, even one of the vessels laden with precious provisions sent by the new company. In early July, David Kirke dropped anchor at Tadoussac, where the signs of French settlement were replaced by Charles I's coat of arms, and the site claimed for himself and his brothers. From Tadoussac, David Kirke ordered a party of ships back downriver to pillage and destroy the remaining French settlements, reserving one of the captured Basque ships, which he delivered upriver to Québec with a letter for Champlain. ${ }^{55}$ Dated July 18th, 1628, Kirke declared in this letter that the 'Commission of the King of Great Britain' provided justification not only for the 'seizure of cattle' and 'boats', but also for the 'taking possession of the lands known as Canada \& Acadia' itself. ${ }^{56}$ Kirke was probably being disingenuous here, but again we cannot know. Conventionally, the function of wartime letters of marque was to facilitate the taking or retaking of moveable property, not immoveable property. These, at least, were the conventions of maritime Europe, even if they appeared not to apply to Atlantic America in this case; or, otherwise, the subtlety of any such distinction was lost on Champlain and his closest advisors who, in their response to Kirke, admitted that 'we are in no doubt about the commissions you have obtained from the King of great Britain'. ${ }^{57}$ In the rest of his deferential reply to the Kirkes, Champlain may have conceded that a great honour had been given to the brothers to execute these, the 'commandments' of their king Charles I, but Champlain remained defiant in his refusal to surrender. For, he wrote, 'by dying in combat we will be honourable'. Downplaying the importance of his losses, and bluffing about an abundance of food reserves in storage at Québec, Champlain was brave in response, but overly optimistic. It is apparent that he expected imminently the arrival of the rest of the fleet sent by the Compagnie de la Nouvelle-France with its fresh provisions and reinforcements. He was therefore probably devastated when he learned of the surrender of these ships to the Kirkes with only the smallest of shows of resistance. ${ }^{58}$

The expedition of the Kirke brothers had yielded plenty of fruit, and quickly: having only reached the Saint-Laurent in May, by August, Cap Tourmente was destroyed and pillaged, Tadoussac was occupied, Québec was seriously threatened, 900 Frenchmen were imprisoned, and some two dozen new ships, along with all their provisions and munitions, were taken as prize. Content with their plunder and fearful, perhaps, of the arrival of French backup, the Kirkes decided to leave Champlain in Québec and make their return to England without delay. The brothers convoyed six of the best prize ships, which were to be sold upon their return to England if not along the way. A few other ships were disarmed and filled with the French captives, and given the freedom to return home. The rest of the captured fleet - the meeker fishing ships - were ignited and left to disintegrate atop the river's surface. ${ }^{59}$

The return of the Kirkes to England at the end of summer caught the attention of many, and inspired something of a revival of enthusiasm among noblemen and merchants about the prospect of taking Québec. The legality of their prizes went unquestioned - claimed as they were during a period of public war and under the authority of a written commission - and the prospect for much greater gains abroad was suddenly championed. ${ }^{60}$ Over in France, nearing what would be the denouement of war, royal forces were making much progress on their goal of repelling the Protestant presence from along the coast. As the captive ships released from the Kirkes pulled into port, the besieged La Rochelle was undergoing a momentous transformation into a bastion of Catholic French control - an event that marked the beginning 
of the end for Charles I's designs across the Channel. ${ }^{61}$ Before the political ramifications of this recapture could entirely be felt in England, however, the Kirkes were making for New France again in March of 1629 in six ships and two pinnaces. Once more they sailed in advance of ships sent by the Compagnie de la Nouvelle-France and an older interest, the Compagnie de Caën, but this time, their head-start would not be advantageous.

Expecting replenishment again in the spring, Champlain was met again by the Kirkes. When one of the pinnaces, displaying a white flag, meandered towards Champlain along the SaintLaurent in July, it carried a letter from Lewis and Thomas. ${ }^{62}$ 'Monsieur', it ran, 'you must hand over the fort and habitation into our hands ${ }^{63}$ Reading this, a dejected Champlain had no choice but to declare his inability to resist the brothers in the manner he had the year earlier. But his surrender, while inevitable, was contingent on a few conditions, he insisted. 'That', held his first and most important article, 'Sir Kirke will reveal the commission of the King of Great Britain, by virtue of which he wants to seize this place, and if it is an act of legitimate warfare between France and England'. ${ }^{64}$ Just why Champlain was so desperate to see David Kirke's letters of marque, which apparently permitted the naturalised Englishman to 'seize this place' in a wartime gesture, is not to be long guessed at. He clearly hoped that his surrender to the Kirkes would be considered a public, rather than a private, cession back in Europe. For this reason, the response of Lewis and Thomas, who told Champlain that neither of them had any royal paperwork to show him, would have jarred his mind: the brothers claimed - with a bluff, perhaps, of their own - that David kept the 'commission' with him at Tadoussac. Champlain was told not to worry, however, for Lewis and Thomas enjoyed 'every power to treat' with him, 'as you will soon see', they confirmed. Champlain was convinced, apparently, and from this point onwards, his position became one of submission to the Kirkes. He along with several other Frenchmen - some of them representing the new company, others the residual traders of the old merchant groups - were taken captive and ferried eastward across the Atlantic by David and Thomas Kirke, who carried the seized furs and munitions with them, leaving Lewis and a trading contingent behind him.

The substance and validity of David Kirke's 'commission' remain something of a mystery. That, following an elaborate ceremony of surrender, both Champlain and David Kirke applied their signatures to Champlain's articles of capitulation suggests that Champlain saw the relevant paperwork and was convinced by what he saw, but this is not at all clear from firsthand accounts. ${ }^{65}$ For all parties involved in the dispute, it remained to be seen whether or not the surrender of Québec would be acknowledged in a post-war context during the diplomatic negotiations associated therewith, and therefore, by extension, whether or not the settlements of Québec and Tadoussac - along with the 1,713 furs taken during the Kirkes's occupation - might be restored to French private interests via the French crown.

Diplomatic developments in Europe transpiring immediately after the departure of the Kirkes for New France would make all the difference in this respect. On April 24th, the Treaty of Susa, foreshadowing the closure of the Anglo-French War, was signed, restoring the 'ancient alliances' and bonne volonté of the two crowns. More specifically, this treaty negated the activity of all vessels 'still at sea with letters of marque', returning 'all seized property [pris] taken within the space of two months to be restored to either side', under the assumption, right as it turned out, that outright peace would prevail between England and France after this period. ${ }^{66}$ Thus could the seizure of Québec in the summer of 1629 be considered a peacetime event, paving the way for its restoration to France during the settlement of terms, the culmination of which was the Treaty of Saint-Germaine-en-Laye in March of 1632. The harmonisation of private and public claims for restitution was therefore set to play an important 
part of these negotiations, as Charles de l'Aubespine, the Marquis de Châteauneuf, made his way to London from Paris to hasten a result, and Sir Thomas Edmondes, now on his final diplomatic mission, made his way to Paris from London for the same purpose. ${ }^{67}$

When David and Thomas Kirke touched at Dover on their return from New France on October 27th 1629, most of their French captives were released for their home passage to be organised. A handful stayed on, bearing uncertain political status in England. Among them was Samuel Champlain. Discovering that his earlier capitulation at Québec had taken place subsequent to the declaration of peace in London and Susa, Champlain now felt a sense of obligation to secure the return of the Laurentinian settlements to the Compagnie de la Nouvelle-France. After he and the others were ferried to London on the 30th, Champlain received an audience with the French ambassadeur extraordinaire, Châteauneuf, to whom he provided a detailed testimony. Together, the pair appear to have reached the conclusion that their best chance of a firstinstance remedy was through the High Court of Admiralty. Admiralty jurisdiction in England, besides hearing prize matters, covered contracts and torts upon the high seas. This jurisdiction quite often extended more broadly than this, controversially, to compete with the courts of common law. Selectively receptive of Roman law and the customary laws of the sea, adjudications of the admiralty courts were more prone to variability than the common law, because juries played no part, precedents were not always revered, judges were often sympathetic towards influential merchants of the ports in question, and appeals, if permitted, went straight to the Chancellor who could intervene personally or arrange for a trial at equity away from the common law. What admiralty lacked in reputation for partiality towards foreigners, however, it made up for with its straightforward approach to rules and evidence concerning simple disputes over unlawful captures at sea. ${ }^{68}$ With cautious optimism, therefore, Champlain approached Sir Henry Marten of the High Court of Admiralty in order to lodge formal statements with the judge on the 7th and 9th of November. These catalogued the Compagnie's miserable stores at the time of the capitulation, but confirmed also that good treatment had been afforded by the Kirkes. ${ }^{69}$ Tellingly, it was also put onto the record 'that no ransom ought to be demanded for their release, as they are not lawful prisoners of war, having been taken upon a plantation', which seemed to imply that a private claim for restitution warranted consideration outside of the circumstances of war. ${ }^{70}$ Shortly after this, Champlain was given leave for Paris where he would make the case for the Compagnie de la NouvelleFrance before Richelieu and Louis XIII personally. While Champlain actively sought the restoration of New France to the Cent Associés, and liaised with several officials in Paris to achieve that end, the separate matter of the furs came to a head in London. David and Thomas Kirke declared before admiralty that they had seized into 'the Companies hands', after the surrender of 'the forte of Quebecke', 'no more than 1713 Beaver Skinnes in the forte \& habitation'; additionally, they claimed to have 'traded w[i]th the Natives of the Countrye for 4540 Beaver Skinnes'. ${ }^{71}$ Those furs apparently acquired through fair trade could not be disputed, the Kirkes claimed. Rather, it was the 1,713 furs, which had been the property not of the Compagnie de la Nouvelle-France, but of its predecessor the Compagnie de Caën, acquired in an act of privateering of dubious legality, that would spark a controversial dispute between these interests. Unlike the Saint-Sauveur fiasco with De Pons, then, moveable property, not immoveable property, would take centre stage in this dispute.

During the second of the raids upon New France, Émery de Caën had been on his final permitted voyage to the St. Lawrence, just after the ratification of the Treaty of Susa, in order to wind off the old company's operations and to retrieve its remaining inventory, when he fell victim to the raids of the Kirkes. When Guillaume de Caën learned of his cousin's misfortune in November, he promptly made his way from France to the Thames in order to have his stolen 
furs restored, if somewhat naïve - as all in his position would have been - of the smoke and mirrors awaiting him at port. De Caën's first step in London was to approach the resident ambassador, just as it had been Champlain's. Châteauneuf, hearing of these separate concerns, was then satisfied to collate them with the demands of the Compagnie de la Nouvelle-France into a Latin memorial for Charles I's attention sometime in January. ${ }^{72}$ Châteauneuf had already received assurances from Charles, back in April of 1629, appearing to suggest that 'restitutio' would be considered for 'Capitane de Caen'. ${ }^{73}$ This time, however, it was the Lords Committee for Foreign Affairs to assume the responsibility for responding to these renewed demands, as Charles, whether embarrassed or indifferent, hid from sight. ${ }^{74}$ In their reply to the ambassador, the lords promised separate investigations into the 'fort \& habitation of Quebic taken by Captayne Kirke', and the 'skinnes brought from Canada'. ${ }^{75}$ The inevitable return of Québec was all but a fait accompli by this stage, but just which court had jurisdiction over the furs, and what kind of jurisdiction that would be - besides, where, how, and why - was all left unsaid. A month passed before a special commission of enquiry composed of London's finest lawyers was launched 'to discover what goods, merchandise, and other things have been taken by Capt. David Kirke' - which, evidently, was proving the more complicated question posed by Châteauneuf. ${ }^{76}$ Testimonies were again collected, before Whitehall unexpectedly intervened. By an Order of the Privy Council of April 2nd, Sir James Campbell, the lord mayor of London, was ordered to auction the disputed furs before only the French and English interests contending for them. ${ }^{77}$ Whomsoever was prepared to make the highest 'offer for the Beaver Skins now in question', the Privy Council confirmed, would receive all the 1,713 furs kept in storage upon payment to the mayor, with the whole process to be supervised by the admiralty judge. ${ }^{78}$ This was presumably intended to speed up the process, but it was hardly a satisfactory outcome for Guillaume de Caën. As he needed to return to France, where his attention was required for domestic legal disputes that would keep him preoccupied until well into the 1640s, De Caën perceived it in his best interest to register the highest bid and retrieve the furs with a view to seeking the restitution of the amount paid later in a separate suit. He tendered 25 shillings per pound and was awarded the prize on April 9th. ${ }^{79}$

After lodging a considerable deposit, however, De Caën was prevented access to the locked warehouse containing the furs. He therefore had to return to France empty-handed. There was only time, before his ship's departure in mid-April, to give power of attorney to Jacques Reynard, and to lodge a petition with the Privy Council threatening a new suit for damages and costs. The Kirkes had evidently outplayed the De Caëns again. And they would continue to do so. When the lord mayor, at the end of the auction, asked for the key to the warehouse, David Kirke refused to hand it over. ${ }^{80}$ When a public notary then approached Kirke after De Caën's departure and asked for the same, the story had changed; now, David Kirke said, the key was lost, with its last known whereabouts being with his mother, who no longer knew where she had put it. ${ }^{81}$ The Kirkes still worked, as they ever had, in a family business! When, two weeks later, the Admiralty intervened and issued a warrant for the Lord Mayor and Sheriffs of London to break into the warehouse and deliver the contents to De Caën's appointed representative, there would be one final act of defiance on the part of the Kirkes. ${ }^{82}$ Only around 300 furs were found inside, some 1,400 less than expected.

Over the next two weeks, it emerged that a Londoner, Thomas Fittz, had received a mysterious tipoff and subsequently paid a bargain price for the furs sometime in April. His apprehension came at the end of the following month. For his 'notorious misdemeanor', Fittz was sent by the Privy Council to the Fleet Prison on July 2nd, and summonsed to appear before the Court of Star Chamber two weeks later. ${ }^{83}$ This was where the Privy Council heard formal trials, and also where the king's personal control over proceedings and outcomes was notorious, 
particularly in trials where fiscal penalties could be imposed. Fittz was a small fry, however, so his detention and interrogation were brief affairs. Because he was prepared to disclose the whereabouts of the missing furs to the Attorney General, the Privy Council looked sympathetically upon his complaints of 'great loss', and so granted his freedom on shortly later on July 14 th. ${ }^{84}$ Finally, a grand total of 1,713 furs were loaded upon a ship bound for Dieppe, where they were reunited with their rightful owner, Guillaume de Caën, but to whom the matter was anything but finished. He was busy preparing a new suit, which went much further than a simple denial that the cost of recuperating the furs was his burden. Now, in the early months of 1631, he claimed a total of 4,266 furs had been wrongfully accumulated by the Kirkes, and moreover he complained about the appropriation of his trading ships and the general impediments to trade left by the Kirkes after 1629. Procedurally, the matter was now more complicated, and called for more diplomatic intervention. In pursuit of his new claims, De Caën presented his complaints to the English ambassador to France, Sir Isaac Wake, sometime in April. Wake's predecessor, Edmondes, does not appear to have shown much concern for the issue before his replacement in early 1630. Lacking sufficient evidence to make any decisive overtures, Wake, in his delicate position, seems to have looked favourably on the De Caëns, as he sought clarification on the discrepancy in the number of furs back in England. ${ }^{85}$

This prompted the sulking return of David Kirke, whose remaining furs were by this stage being held under sequestration by Admiralty, to Henry Marten on May 27th, $1631 .{ }^{86}$ For the first time, he was forced onto the defensive. He reiterated his original statements and maintained a firm distinction between furs traded and furs seized. Their 'Commission under the broade seale of England', he reminded Marten, had permitted the brothers 'utterly to expell [the French] from that Country'. After doing so, all the furs acquired in Québec came into his possession lawfully through trade, not by theft, he declared. ${ }^{87}$

In France, a different interpretation prevailed. After Émery and Guillaume de Caën registered their request for recompense with a mobile French court commissioned especially by Louis XIII to make a record of outstanding grievances before the negotiations of the final peace, the cousins grew in confidence. As neither the Kirkes nor any of their representatives were present at the relevant hearing of the court, the figures claimed by the Compagnie de Caën here went unchallenged. ${ }^{88}$ Wake was powerless, at this stage, to intervene, and could do no more than send warnings home about the claim for 4,266 furs. The High Court of Admiralty in London then prepared to be faced with the requests of the De Caën cousins for damages once more. Throughout the winter months of late 1631 and early 1632, duplicates were ordered from the court of all relevant inventories and testimonies. These were sent quickly to Wake, whom everyone in England and Scotland increasingly hoped would be able to resolve the affair without further significant investigation. ${ }^{89}$

Wake in this period was consumed with negotiations in Saint-Germaine-en-Laye, where all matters of restitution, public and private, were finally slated for consideration. Here, the differences of opinion between the Kirkes and the De Caëns were definitively to be addressed not by themselves or by their solicitors but by their diplomatic countrymen. Wake, still apparently sympathetic to the De Caën cousins, resolved to see their claims honoured in these negotiations. Upon the great balance sheet of the profits and losses compiled in this period, he uncritically accepted the figures presented to him by the French and overlooked the original depositions collected back in November of 1629. This was a large claim for damages, reaching a total of $£ 14,330$ ( $£ 8,270$ for the furs, plus $£ 6,060$ for losses in the trade and the appropriation of ships belonging to the Compagnie de Caën). When news of this sum reached England, it was reputed with much indignation. The Kirkes were completely caught off-guard. They and 
the other 'Canada adventurers' expected Wake to advance their own interests at the bargaining table, not those of the Compagnie de Caën. Instead, as they complained in a long and detailed letter of protest to Wake, their own predicament had been disregarded. They were prepared to admit the need to 'have made restitution' with the French. But to their minds, such restitution needed only to have covered the value of the goods actually taken from the stores of Québec and the ship of Émery de Caën and nothing more. ${ }^{90}$ Crucially, however, the Kirkes were no longer directly concerned in the matter. When Wake gave his formal assurances to the De Caëns that a large sum would be paid them for compensation, the Kirkes were not the ones left with the responsibility for covering it. Instead, that responsibility fell to Charles I. For this reason, the secretary of state, Sir John Coke, and the Chancellor of the Exchequer, Lord Francis Cottington, were both aghast to learn of Wake's generosity. They felt that the English diplomat to France had yielded when he ought not have, burdening Charles I with a debt exorbitantly excessive of the true value of the damages. The king reluctantly authorised the payment - or, more accurately, consented to its deduction from the amount owed him by the French - and the public component of this legal dispute came to an end. ${ }^{91}$

The extraordinary private dispute between the Kirkes and the De Caëns endured beyond the signing of the Treaty of Saint-Germaine-en-Laye. Émery de Caën, whom Richelieu nominated in 1632 to oversee the withdrawal of the English from Québec, was stalled throughout late June and July by Lewis Kirke and his colleagues, who had kept the fort since 1629. The credentials of De Caën, they argued, were deficient of authority to evict them from New France! They could hold this line while dragging their feet for no longer than a few weeks, though, before giving up Québec in mid-July - apparently, however, engulfed in flames. So the De Caën cousins found themselves once again with another claim for outstanding damages. Although Richelieu offered his soothing assurances to Guillaume that he would soon have his remedy, effectively it was his own manoeuvre - handing the keys of New France to the Compagnie de la Nouvelle-France - which put Samuel de Champlain back in the driving seat and squeezed the De Caëns out of the picture for good. ${ }^{92}$ The details of what follows are sketchy, but it can only be suggestive of his misfortunes that Guillaume's name shows up a few times among the subjects of malady in the records of the Amiraute de France in 1642, the central admiralty court where lodgements could be made directly or otherwise on appeal from one of the dozens of miniature admiralty courts situated along the coast of France. ${ }^{93}$ In one such instance, Guillaume's name appears upon an application for a writ against the Kirkes to the tune of 137,000 livres. ${ }^{94}$ This request does not appear to have been redirected to the king or his conseil, and so, it seems, was allowed to subside in the interests of preserving the hesitant alliance between England and France during the latter stages of the Thirty Years War. The Kirkes likewise sought restitution for many years after their humiliation in 1632, and not only that, they sought revenge. Complaining of the costs associated with the abandonment of the trade, the evacuation of Québec, and the delivery of remaining inventory back to Europe, the brothers registered their demands of more than $£ 4,000$ from Guillaume de Caën with Secretary Coke in 1633. Coke may have looked sympathetically on their claim, but with the peacetime negotiations well and truly wrapped up, there was little scope for the suit to be brought by any ambassadors, and no court ambitious enough to exercise jurisdiction either side of the Channel. The next step of the Kirkes was telling: to make several requests between 1633 to 1636 for 'the King's letters', so that they might 'right themselves' in Canada. Their efforts in England, and subsequent activities on the St. Lawrence and in Newfoundland, would ultimately prove ineffective to that end. ${ }^{95}$

\section{CONCLUSION}


Focusing upon 'private undertakings' in conflict with one another off the distant coastlines of the Atlantic world allows for a better understanding of some of the peculiar relationships that were developing between commercial interests and resident ambassadors in early modern Europe. Through these relationships were the conditions generated for the first attempts to resolve disputes emerging away from Europe through legal and political institutions set within it.

Both case studies in this article highlight how important it was for the earliest merchant interests in the Atlantic New World to have resident ambassadors vouching for them in England and France. The language of tort, central to which were the concepts of damaged interests and personal liabilities, was more effectively mobilised than making recourse to the 'law of nations', whatever that was in this period. But it was never easy to proceed much further than issuing a complaint. Sometimes diplomats failed to find a forum in which to register protests or counter-protests on behalf of private interests. At other times, they were expected to sacrifice smaller claims altogether in the interests of advancing heftier matters of state. Private actors, for their part, had to take every opportunity they could get to have their particular pleas heard. Sometimes this meant bending the truth, exaggerating the value of losses, concealing evidence, or just dallying.

The principal utility of this comparison is its exposure of the impact of war and peace upon private claims for restitution. Depredations committed during wartime, under the authority of letters of marque, were treated very differently to those which were not. Both voyages of Argall, and the second of the two voyages of the Kirkes, carried very different legal consequences in Europe to the first voyage of the Kirke brothers, it emerges here. And everyone knew it. Champlain, of the Compagnie de la Nouvelle-France, in collusion with Châteuneuf, the special ambassador, was noticeably eager to clarify that the French captives were 'not lawful prisoners of war', but were rather 'taken upon a plantation', after the peace of Susa. Over the next three years, as peacetime negotiations consumed elected statesmen from England and France, the De Caën cousins pressed for their private claims to be placed upon the agenda too - an avenue which would not have been available to them had the war in the Channel gone on for a few months longer than it did. Prior to this, it had been the Kirkes who first played on the distinction between plundering through war, and accumulating through trade, in order to separate the public legal issues from the private legal issues associated with the capture and return of Québec. But in the end it was the Compagnie de Caën to use this context best to its gain and became the recipients of $£ 14,330$. This might have been somewhat too generous, but regardless it was certainly far greater than would have been awarded were it not for the willingness of Wake to consider the claim at face value. Thus were private claims for damages subsumed within a public act of restitution, largely on the whims of the ambassadors involved, and without much input, in the end, from the courts.

Trading companies extending themselves beyond their home jurisdictions into the extraEuropean world knowingly took a risk, investing pools of capital into expeditions bound for unpredictable and largely unknown markets. The risk of this investment was amplified by the presence of other Europeans, which was by no means an insignificant variable. A competitive trade made life more difficult for companies in the New World. Of course, competitive markets were annoying to companies in the free ports of Europe too. But what was unique to the extraEuropean world in the early seventeenth century was the absence of local and unbiased avenues for redress in the event of damages incurred upon the particular interests operating there. If these conditions and others like them are profitably to be seen to represent a state of 'legal pluralism', then it might be important to qualify that each group of foreign interests operating 
along the coasts and 'corridors' of the New World were always inclined to abide by their own rules and procedures unless - or until - coercion by force of arms made legal seclusionism of this kind no longer feasible. Episodic violence was sometimes justified by letters of marque but at other times required no justification. This was no context congenial to dispute resolution.

A predicament of jurisdictional deficiency was disadvantageous to all merchants attempting to profit from foreign markets. Even if the more substantive kind of 'company-state' bore less of this burden than the smaller companies did, it remains noteworthy that all private interests, whether individual or corporate, found themselves relying upon state actors to rehearse their claims for damages through existing judicial and diplomatic organs within their metropolitan European domiciles. This is of some importance. However imperfectly grievances about 'grand torts' abroad were aired by those involved in all such cases, it was through this kind of advocacy that some of the earliest distinctions were made between private international law and public international law in European history, regardless of how rudimentarily and crudely these interventions appear in relation to more modern efforts to fortify the same distinction. ${ }^{96}$ Only during the long nineteenth century would courts in Europe and America develop more accommodating jurisprudence in regard to 'alien torts' and 'conflicts of laws'. Paradoxically, however, this led to costlier and fussier litigation, and accordingly, more arbitration and settlements away from courts. Well before all of this took place, there was a brief period in early modern history in which it made sense to establish basic standards, and to erect special judicial institutions, for trading companies interacting with each other in the New World. Such moves never took place, it might be speculated, for two principal reasons. First of all, this would have been too far out of step with the politics of mercantilism, which saw the unification of policies of war and trade by national legislatures in this period. The other factor to consider is the growth in power of the European state, which was centralising, rather than delegating, its authority over subjects at home and abroad. That international law was so determined by intranational developments is part of what makes this subject so intriguing, and yet so subjective for any historian attempting to locate its exact 'origins' or beginnings.

\section{Archival sources}

Centre des Archives Diplomatiques du Ministère des Affaires Étrangères (AD).

Correspondance Politique (Angleterre) (CPA)

Archives Nationales, Paris, France (ANF) 
Amirauté de France

British Library, London, United Kingdom (BL)

Cotton MS

Egerton MS

Bibliothèque Nationale de France, Paris, France (BNF)

Libraries and Archives Canada, Ottawa, Canada (LAC)

National Archives of the United Kingdom. London, United Kingdom (NAUK)

Colonial Office (CO)

Privy Council (PC)

State Papers (SP)

\section{Published primary sources}

The Manuscripts of Earl Cowper. 2 Volumes. Historical Manuscripts Commission. London: Her Majesty's Stationery Office, 1888 (CM).

Calendar of State Papers. Multiple Volumes. Series consulted include: Domestic; Colonial (West Indies and America); Colonial (East Indies, China and Japan); Venice. Multiple Editions. 1509-present (CSP).

Hakluytus Posthumus, or Purchas his Pilgrimes. 20 Volumes. Edited by Samuel Purchas. Glasgow: Glasgow University Press, $1906(H P)$.

The Jesuit Relations and Allied Documents, 1610-1791. 71 Volumes. Edited by Reuben Gold Thwaites. Cleveland: Burrows Brothers, 1896-1901 (JR).

Monumenta Novae Franciae. 9 Volumes. Edited by Lucien Campeau. Rome: Monumenta Hist. Soc. Iesu, 1967-present (MNF).

Nouveaux Documents sur Champlain et Son Époque. Edited by Robert Le Blant and René Baudry. Ottawa: Publications des Archives Publiques du Canada, 1967 (NDCE).

Oeuvres de Champlain. Written by Samuel de Champlain. 5 Volumes. Second edition edited by C.-H Laverdière. Québec: Imprimé au Séminaire, 1870 (OC).

Records of the Virginia Company of London. 4 Volumes. Edited by Susan Myra Kingsbury. Washington: Government Printer, 1906-35 (RVCL).

Yale Avalon Project, http://avalon.law.yale.edu/default.asp, accessed 13 March 2017 (YAP).

Beaumanoir, Phillipe de Remi, Sire de. Coutumes de Beauvaisis. Paris: Picard, 1900. 
Bernardi de Rosergio, Ambaxiator Brevilogus (1436), in Vladimir E. Hrabar, ed., De Legatis et Legationibus Tractatus Varii. Dorpat: Typographeo Mattieseniano, 1905.

Chaplais, Pierre, ed. English Diplomatic Practice, Part I. Two volumes. London: PRO, 1982.

Davenport, Francis, ed. European Treaties Bearing on the History of the United States and its Dependencies. Two volumes. Washington, D.C.: Carnegie Institute of Washington, 1917.

Grotius, Hugo. Commentary on the Law of Prize and Booty, edited by Martine Julia van Ittersum. Indianapolis: Liberty Fund, 2006.

Hamor, Ralph. A True Discourse of the Present State of Virginia, and the Success of the Affaires There till the 18 of Iune, 1614. London: John Beale, 1615.

Thomas, A. H., ed. Calendar of Early Mayor's Court Rolls. Cambridge: Cambridge University Press, 1924.

Thorpe, Francis Newton, ed. The Federal and State Constitutions Colonial Charters, and Other Organic Laws of the States, Territories, and Colonies Now or Heretofore Forming the United States of America. Washington, DC: Government Printing Office, 1909.

\section{Secondary sources}

Argúas, Margarita. "The Montevideo Treaties of 1889 and 1940 and Their Influence on the Unification of Private International Law in South America." In The Present State of International Law and Other Essays, edited by Maarten Bos, 345-60. Deventer: Kluwer Press, 1973.

Baldwin, James Fosdick. The King's Council in England during the Middle Ages. Oxford: Clarendon Press, 1913.

Benton, Lauren and Ross, Richard J. eds. Legal Pluralism and Empires, 1500-1850. New York: New York University Press, 2013.

Benton, Lauren. "Colonial Law and Cultural Difference: Jurisdictional Politics and the Formation of the Colonial State." Comparative Studies in Society and History 41: 3 (1999): 563-588.

Benton, Lauren. "The Legal Regime of the South Atlantic World, 1400-1750: Jurisdictional Complexity at Institutional Order.” Journal of World History 11: 1 (2000): 27-56.

Benton, Lauren. "Toward a New Legal History of Piracy: Maritime Legalities and the Myth of Universal Jurisdiction.” International Journal of Maritime History 23: 1 (2011): 225-40. 
Benton, Lauren. A Search for Sovereignty: Law and Geography in European Empires, 14001900. Cambridge: Cambridge University Press, 2010.

Biggar, Henry Percival. The Early Trading Companies of New France: A Contribution to the History of Commerce and Discovery in North America. Toronto: University of Toronto Library, 1901.

Bosher, John. "The Political and Religious Origins of La Rochelle's Primacy in Trade with New France, 1627-1685.” French History 7 (1993): 286-312.

Burdick, William Livesey. The Principles of Roman Law and Their Relation to Modern Law. Rochester, N.Y.: Lawyers Cooperative Publishing Company, 1938.

Cavanagh, Edward. "Corporations and Business Associations from the Commercial Revolution to the Age of Discovery: Trade, Jurisdiction and the State, 1200-1600." History Compass 14: 10 (2016): 493-510.

Chavarot, Marie-Claire. "La Pratique des Lettres de Marque d'après les Arrêts du Parlement (XIIIe-début XVe siècle).” Bibliothèque de l'École des Chartes 149: 1 (1991): 51-89.

Clanchy, M. T. From Memory to Written Record: England, 1066-1307, 2nd edition. Oxford: Blackwell Publishers, 1993.

Clulow, Adam. The Company and the Shogun: The Dutch Encounter with Tokugawa Japan. New York: Columbia University Press, 2014.

Cogswell, Thomas. The Blessed Revolution: English Politics and the Coming of War, 16211624. Cambridge: Cambridge University Press, 2005.

Dawson, John P. "The Privy Council and Private Law in the Tudor and Stuart Periods: I and II.” Michigan Law Review 48 (1950): 393-428, 627-56.

De Saint-Père, Rameau. Une Colonie Féodale en Amérique L'Acadie (1604-1881). Montréal: Granger Frères, 1889.

Desbarats, Catherine and Greer, Allan. "Où est la Nouvelle-France?" Revue d'Histoire de l'Amerique Française 64 (2011): 31-62.

Dewar, Helen. "YY establir nostre auctorité": Assertions of Imperial Sovereignty through Proprietorships and Chartered Companies in New France, 1598-1663'. PhD diss., University of Toronto, 2012.

Dewar, Helen. "Litigating Empire: The Role of French Courts in Establishing Colonial Sovereignties." In Legal Pluralism and Empires, 1500-1850, edited by Lauren Benton and Richard J. Ross, 49-79. New York: New York University Press, 2013.

Dicey, A. V. A Digest of the Law of England with Reference to the Conflict of Laws, with notes of American Cases by John Bassett Moore. London: Stevens and Sons, 1896.

Dicey, A. V. The Privy Council. London: Macmillan and Co., 1887. 
Fedele, Dante. "Naissance de la Diplomatie Moderne: L'Ambassadeur au Croisement du Droit, de l'Éthique et de la Politique." PhD dissertation, University of Lyon, 2005.

Folsom, George. "Expedition of Captain Samuel Argall, afterwards Governor of Virginia, Knight, and to the French Settlements in Acadia and to Manhattan island, A. D. 1613." Collections of the New York Historical Society (1841), 1: 333-42.

Greengrass, M. "Winwood, Sir Ralph (1562/3-1617)." Oxford Dictionary of National Biography, http://www.oxforddnb.com/view/article/29783, accessed 13 July 2016.

Groebner, Valentin. "Describing the Person, Reading the Signs in Late Medieval and Renaissance Europe: Identity Papers, Vested Figures, and the Limits of Identification, 14001600'." In Documenting Individual Identity: The Development of State Practices in the Modern World, edited by Jane Caplan and John Torpey, 15-27. Princeton: Princeton University Press, 2001.

Heidecker, Karl, ed. Charters and the Use of the Written Word in Medieval Society. Turnhout: Brepolspublishers, 2000.

James, Alan. The Navy and Government in Early Modern France, 1572-1661. Woodbridge: Boydell Press, 2004.

Johanek, Peter. "Zur Rechtlichen Funktion von Traditionsnotiz, Traditionsbuch und Früher Siegelurkunde." In Recht und Schrift im Mittelalter, edited by Peter Classen, 131-62. Sigmaringen: Thorbecke, 1977.

Kirke, Henry. The First English Conquest of Canada, 2nd ed. London: Sampson Low, Marston \& Co., 1908.

Le Blant, Robert. "La Compagnie de la Nouvelle-France et la Restitution de l'Acadie (16271636)." Revue d'Histoire des Colonies 42: 146 (1955): 69-93.

Le Blant, Robert. "Les Débuts Difficiles de la Compagnie de la Nouvelle-France: L'Affaire Langlois, 1628-1632." Revue d'Histoire de l'Amérique Française 22: 1 (1968): 25-34.

MacBeath, George. "Du Gua de Monts, Pierre." Dictionary of Canadian Biography, http://www.biographi.ca/en/bio/du gua de monts pierre_1E.htm, accessed 13 July 2016.

Macmillan, Ken. Sovereignty and Possession in the English New World: The Legal Foundations of Empire, 1576-1640. Cambridge: Cambridge University Press, 2006.

MacMilllan, Ken. "Common and Civil Law? Taking Possession of the English Empire in America, 1575-1630." Canadian Journal of History 38 (2003): 409-23.

Mathiasen, Joanne. "Some Problems of Admiralty Jurisdiction in the 17th Century." American Journal of Legal History 2: 3 (1958): 215-36.

Mattingly, Garrett. Renaissance Diplomacy. New York: Dover Publications, 1988. 
Morieux, Renaud. The Channel: England, France and the Construction of a Maritime Border in the Eighteenth Century. Cambridge: Cambridge University Press, 2016.

Mousnier, Roland. The Institutions of France under the Absolute Monarchy, II: The Organs of State and Society. Chicago: University of Chicago Press, 1984.

Neuhauser, Paul M. "Privy Council and the Regulation of Trade under James." Iowa Law Review 50 (1965): 1032-72.

Nicholls, Andrew. A Fleeting Empire: Early Stuart Britain and the Merchant Adventurers to Canada. Toronto and Montreal: McGill-Queens University Press, 2010.

Nordman, Daniel. "Sauf Conduits et Passeports, en France, à la Renaissance." In Voyager à la Renaissance, edited by Jean Ceard and Jean-Claude Margolin, 145-58. Paris: Maisonneuve et Larose, 1987.

Parkman, Francis. France and England in North America. Boston: Little, Brown and Co., 1874.

Parrott, David. Richelieu's Army: War, Government, and Society in France, 1624-1642. Cambridge: Cambridge University Press, 2004.

Pope, Peter E. Fish into Wine: The Newfoundland Plantation in the Seventeenth Century. Chapel Hill: University of North Carolina Press, 2004.

Pouliot, Leon. "Que Penser des Frères Kirke?" Bulletin des Recherches Historiques 44: 11 (1938): 321-335.

Reeve, L. J. Charles I and the Road to Personal Rule. Cambridge: Cambridge University Press, 1989.

Reid, John G. "The Scots Crown and the Restitution of Port Royal, 1629-1632." Acadiensis 6: 2 (1977): 39-63.

Reid's, John G. Acadia, Maine and New Scotland: Marginal Colonies in the Seventeenth Century. Toronto: University of Toronto Press, 1981.

Robbins, Kevin C. City on the Ocean Sea: La Rochelle, 1530-1650: Urban Society, Religion, and Politics of the French Atlantic Frontier. Leiden: Brill, 1997.

Ryder, Huia. "Biencourt de Poutrincourt et de Saint-Just, Jean de." Dictionary of Canadian Biography,http://www.biographi.ca/en/bio/biencourt de poutrincourt et de saint just jean de 1E.html, accessed 13 July 2016.

Scott, James B. The State in Early Modern France, 2nd ed. Cambridge: Cambridge University Press, 2009.

Seed, Patricia. "Taking Possession and Reading Texts: Establishing the Authority of Overseas Empires." William and Mary Quarterly 49: 2 (1992): 183-209. 
Smith, Thomas. De Republica Anglorum: The Maner of Gouernement or Policie of the Realme of England. London: Henrie Midleton, 1583 (1565).

Steckley, George F. "Merchants and the Admiralty Court during the English Revolution." American Journal of Legal History 22: 2 (1978): 137-75.

Stern, Philip J. The Company-State: Corporate Sovereignty and the Early Modern Foundations of the British Empire in India. Oxford: Oxford University Press, 2011.

Stith, William. The History of the First Discovery and Settlement of Virginia. Williamsburg: William Parks, 1747.

Tai, Emily Sohmer. "Law of Marque." In Trade, Travel, and Exploration in the Middle Ages: An Encyclopedia, edited by John Block Friedman and Kristen Mossler Figg, 338-9. Routledge: New York, 2000.

Tapié, Victor Lucien. France in the Age of Louis XIII and Richelieu, trans. D McN. Lockie. Cambridge: Cambridge University Press, 1984 (1967).

Trivellato, Francesca. “Amphibious Power': The Law of Wreck, Maritime Customs, and Sovereignty in Richelieu's France." Law and History Review 33: 4 (2015): 915-44.

Trudel, Marcel. “Caën, Guillaume de." Dictionary of Canadian Biography, http://www.biographi.ca/en/bio/caen guillaume de 1E.html, accessed 13 July 2016.

Trudel, Marcel. The Beginnings of New France, 1524-1663, trans. Patricia Claxton. Toronto: McClelland and Stewart, 1973.

van Ittersum, Martine Julia. Profit and Principle: Hugo Grotius, Natural Rights Theories and the Rise of Dutch Power in the East Indies 1595-1615. Leiden: Brill, 2006.

Westlake, John. A Treatise on Private International Law: Or the Conflict of Laws, with Principal Reference to Its Practice in the English and Other Cognate Systems of Jurisprudence. London: W. Maxwell, 1858.

Weststeijn, Arthur. "The VOC as a Company-State: Debating Seventeenth-Century Dutch Colonial Expansion." Itinerario 38: 1 (2014): 13-34.

Wubs-Mrozewicz, Justyna, and Wijffels, Alain. "Diplomacy and Advocacy: The Case of the King of Denmark v. Dutch Skippers before the Danzig City Council (1564-1567)." Tijdschrift voor Rechtsgeschiedenis 84 (2016): 1-53.

Zaller, Robert. "Martin, Richard (1570-1618)." Oxford Dictionary of National Biography, http://www.oxforddnb.com/view/article/18206, accessed 13 July 2016.

\section{Notes:}


${ }^{1}$ See especially Stern, Company-State; Weststeijn, “The VOC as a Company-State.”; Clulow, Company and the Shogun; van Ittersum, Profit and Principle. For the medieval background to this story, see Cavanagh, "Corporations and Business Associations."

${ }^{2}$ Benton, "The Legal Regime of the South Atlantic World."; Benton, "Toward a New Legal History of Piracy."; Benton, "Colonial Law and Cultural Difference." See also Benton and Ross, Legal Pluralism and Empires.

${ }^{3}$ Benton, A Search for Sovereignty.

${ }^{4}$ Chavarot, "La Pratique des Lettres de Marque d'après les Arrêts du Parlement (XIIIe-début XVe siècle)."; Tai, "Law of Marque." For some good examples of early English letters of marque, see Chaplais, English Diplomatic Practice, 1: 382-6.

${ }^{5}$ For charters in the Middle Ages, see Heidecker, Charters and the Use of the Written Word; Johanek, "Zur Rechtlichen Funktion von Traditionsnotiz, Traditionsbuch und Früher Siegelurkunde."; Clanchy, From Memory to Written Record. For letters of reference and identity documentation - which still fell far short of the capability of declaring conditions over foreigners - see Groebner, "Describing the Person, Reading the Signs in Late Medieval and Renaissance Europe."; Nordman, "Sauf Conduits et Passeports." For the observation true to Roman legal tradition that no donation, 'whether divine or human' could affect 'the property of others', see Grotius, Commentary on the Law of Prize and Booty, 310. Nevertheless, compare MacMilllan, "Common and Civil Law?"; Seed, "Taking Possession and Reading Texts."

${ }^{6}$ Marc Antonio Correr to the Doge and Senate (27 February 1609), CSP Venice 11: 237.

${ }^{7}$ As Bernard du Rosier first explained, the public utility of ambassadors was immeasurable due to the multiple roles they performed in their representative capacity for their sending authority (republica). If some of these roles were principally ceremonial, and others were principally negotiational, in all duties the interests represented were only ever public, and seldom if ever private. An ambassador's mandate was only to enter into treaties respecting such public affairs as were clearly specified by whichever prince, city-state, kingdom, or community he represented. Rosergio, Ambaxiator Brevilogus. In the sixteenth century, it was rare but not entirely unheard of for diplomats to advocate on behalf of private interests in foreign courts across Europe, but the results of these efforts were so uneven (and contingent upon a number of variables pertaining, for instance, to the specificities of treaty relationships, the peculiarities of changing court cultures, right down to the individual proficiency of legal thinkers and representatives) that it remains difficult to generalise about this activity. See, however, WubsMrozewicz and Wijffels, "Diplomacy and Advocacy." For context, see Mattingly, Renaissance Diplomacy, 25-54; Fedele, "Naissance de la Diplomatie Moderne," esp. discussion at 131-8.

${ }^{8}$ Macmillan, Sovereignty and Possession, 194-7, which is made in the context of an argument about royal expressions of public authority abroad.

${ }^{9}$ See, most recently, Nicholls, Fleeting Empire. For details on the divergence of Scottish and French points of view, compare Reid, "The Scots Crown."; Le Blant, "La Compagnie de la Nouvelle-France." See also generally Macmillan, Sovereignty and Possession, 197-201; Biggar, Early Trading Companies, 150-66; Parkman, France and England in North America, 1: 401-20.

10 The first, second, and third Virginia charters are easiest to consult at YAP, which are reproductions of those found in Thorpe, Federal and State Constitutions. All dates here and hereafter are in New Style. 'Virginia Company' after the inactivity of the Plymouth Company should imply the Virginia Company of London. 
${ }^{11}$ Letter of Samuel Argall (June 1613), in Purchas, Hakluytus Posthumus, 19: 92-3; Hamor, A True Discourse, 4-8. Within the space of about a decade, it became common for Virginia to send tobacco north to trade for fish from the Newfoundland Company. For the economics of the cod fishery in this period, see Pope, Fish into Wine.

${ }^{12}$ For a critical reading of the name 'New France', see Desbarats and Greer, "Où est la Nouvelle-France?."

13 Some of these overlapping grants became defunct through disuse while others were transferred between interests in the name of speculation, leading to successive suits and enquiries into the many contradictory privileges of merchants and investors in the courts and parlements of France. See Dewar, "'Y establir nostre auctorité."; Dewar, "Litigating Empire". ${ }^{14}$ See the Receipt ('reconnaissance') of René Le Coq, Sieur de la Saulsaye (17 August 1612), NDCE 1: 228-9.

${ }^{15}$ BL Cotton MS Otho. E 8: 252-3; JR 2: 247-65; 3: 5-7.

${ }^{16} J R$ 2: 255-6.

${ }_{17}^{17} J R$ 4: 9-10; OC 5: 774-5. My translation here and hereafter for all French.

${ }^{18} J R$ 4: 32-7.

19 De Saint-Père, Une Colonie Féodale, 1: 50-62, quote at 51; Trudel, Beginnings of New France, 85.

${ }^{20} J R$ 4: 37-49.

${ }^{21}$ Here Argall found the small Dutch settlement of the Amsterdam-based Van Tweenhuysen Compagnie. He had time only to declare to Hendrick Christiaenszoon, the principal factor of the post, that the entire island was his own personal estate by virtue of a grant from the Virginia Company of London via the English crown. Although this allegation was wild in the extreme, Christiaenszoon, possessed of no means to resist or dispute, apparently submitted graciously to Argall. See Captain John Mason to Sir John Coke (2 April 1632), NAUK CO 1/6, 129; Stith, History of the First Discovery, 132-3. Our understanding is plenty hindered by patchy and contradictory evidence. See, for an introduction, Folsom, "Expedition of Captain Samuel Argall."

22 JR 4: 49-75.

23 Henri de Montmorency to James I (28 October 1613), NAUK SP 78/61/96, 284.

${ }^{24}$ Samuel Spifames to Pierre Brulart (19 December 1613), and the Memoire de Samuel Spifames (28 December 1613), BNF Ms fr. 15987, 167-8, 400-1. See also MNF 1: 295-7.

${ }^{25}$ Spifames to Pierre Brulart (3 May 1614), BNF Ms fr. 15987, 231-5; MNF 1: 412. Much can be taken from Spifames papers, kept at the Bibliotheque Nationale, Paris. He certainly earned his keep. Almost single-handedly, Spifames appears to have orchestrated a great spike of French complaints in the winter and spring of 1614, not only about Acadia and the Jonas, but also about the travails of tussling fishermen off the coasts of Newfoundland and Greenland. What is interesting, and cannot easily be explained, is the openness of the English to consider the 'liberte de la pescherie' off the coast of Newfoundland but not in the Greenland seas in this period before, of course, the interventions of John Selden in Mare Clausum (1635), which requires the concentration of another historian, but see for example the Answer to the French Complayntes (1614) NAUK SP 103/9/4, 273-4.

${ }^{26}$ Smith, De Republica Anglorum, 43-4.

${ }^{27}$ Neuhauser, "Privy Council and the Regulation of Trade."; Dawson, "The Privy Council and Private Law in the Tudor and Stuart Periods, I and II." For the evolution of the Privy Council from the Norman curia regis to become, by the second half of the sixteenth century, an appointed body of advisors for matters of state, foreign affairs, and review, see Baldwin, King's Council; Dicey, Privy Council.

${ }^{28}$ Minutes of the Privy Council (2 February 1614), NAUK PC 2/27, 121.

${ }^{29}$ JR 4: 77-8. 
${ }^{30}$ MacBeath, "Du Gua de Monts, Pierre."

31 "Le sieur de Poitrincourt père ayant obtenu un don du Sieur de Mons, en vertue de sa commission, de quelques terres adjacents au port Royal." $O C$ 5: 766; see also 3: 172-8.

${ }^{32}$ NDCE 1: 163, 237, 242-3, 276, 344, 368.

${ }^{33}$ Ryder, "Biencourt de Poutrincourt et de Saint-Just, Jean de."

${ }^{34}$ It was held in the European ius civile that mutes, deafs, lunatics, madmen, minors and women were prohibited from making direct entry into contracts. Burdick, Principles of Roman Law, 392-4; Beaumanoir, Coutumes de Beauvaisis, 2: 35, n. 1061.

${ }^{35}$ OC 5: 770-1.

${ }^{36}$ See the Receipt ('reconnaissance') of René Le Coq, Sieur de la Saulsaye, for the sum of 750 livres received from Jean de Biencourt, Sieur de Poutrincourt, towards half the cost of outfitting a ship for Acadia; the remaining half of the expenses to be borne by the Marquise de Guercheville, a lady-in-waiting to the Queen Regent (17 August 1612), NDCE 1: 228-9.

${ }^{37}$ Spifames to Sir Ralph Winwood (1 June 1614), BNF Ms fr. 15987, 249-50; MNF 1: 423-4. Winwood was an experienced diplomat, a Privy Councillor, and, after his replacement of Robert Cecil as Secretary of State in 1614, a disliked member of the Commons. See Greengrass, "Winwood, Sir Ralph (1562/3-1617)."

${ }^{38}$ JR 4: 77-8; Spifames to Brulârt (22 June 1614), BNF Ms fr. 15987, 265-6; MNF 1: 429-30.

39 Answer to the Complaints presented to the King by the Sieur de Buisseaux, French Ambassador, at the Court of his Majesty (1614), CSP Colonial, America and West Indies 9: 53-54.

${ }^{40}$ Rapport de Charles Fleury, Maitre du Jonas (27 August 1614), MNF 1: 442-4.

${ }^{41}$ De Pons to Winwood (21 October 1614), NAUK SP 78/62/68, 165.

${ }^{42}$ Spifames to Brulart (19 November 1614), BNF Ms fr. 15987, 359-363.

${ }^{43}$ Response of the Virginia Company of London to the Complaints of the French Ambassador (nd., 1614), BL Cotton Ms Otho. E8, 232. Martin, who represented the company from 1612 onwards, was also a noted tavern comedian, and probably a co-author of wonderfully impolite poem, 'The Parliament Fart'. Zaller, "Martin, Richard (1570-1618)."

${ }^{44}$ Response of the Virginia Company of London to the Complaints of the French Ambassador (nd., 1614), BL Cotton Ms Otho. E8, 232. The emphasis here is in original.

${ }^{45}$ Response of the Virginia Company (1614), BL Cotton MS Otho. E8, 233.

${ }^{46}$ This is indeed what the Dutch had been arguing all along, insisting instead upon making entry into contracts with local communities. See for example Wouter van Twiller to John Winthrop (4 October 1633 [Sept 24 o.s.]), NAUK CO 1/6, 213.

${ }^{47}$ Fleury, in his report, concluded that Argall must have had seized ('saisis et emparez') the royal commission from the chest of the Jonas, which tied in quite nicely with Biard's somewhat less ecumenical explanation published in the Relations later in 1618, that 'all of us had come into the power of the English Heretic, who, being extremely crafty, secretly abstracted from La Saussaye's trunk the Royal commission'. Rapport de Charles Fleury, Maitre du Jonas (27 August 1614), MNF 1: 443; JR 2: 254-5. Just why de Pons and Spifames made nothing of the matter throughout all of this - and correspondingly why it was that Argall never had to answer for it - might encourage more speculation that the chest never contained any such commission. It might be telling here that over a similar matter earlier in 1614, Spifames had been warned by the secretary of state not to lay too much emphasis on 'de lettres Patentes du defunct Roy trixchristien'. Answer to the Complaints presented to the King by the Sieur de Buisseaux, French Ambassador, at the Court of his Majesty (1614), NAUK SP 103/9/4, 273.

${ }^{48}$ Sir Thomas Edmondes to Winwood (12 December 1614), NAUK SP 78/62/95, 241.

${ }^{49}$ Cogswell, The Blessed Revolution; Parrott, Richelieu's Army, 1-109.

${ }^{50}$ For this conflict within a wider context, see Tapié, France in the Age of Louis XIII; Reeve, Charles I and the Road to Personal Rule. 
${ }^{51}$ For the Channel as a lively and open place of circulation in this period, see the remarkable study of Morieux, The Channel, esp. 60-106.

${ }^{52}$ Kirke, The First English Conquest of Canada, 33-64; Pouliot, "Que Penser des Frères Kirke?"

${ }^{53}$ Nicholls, Fleeting Empire, 69-86.

${ }^{54}$ Beyond the record of a warrant for letters of marque in the Domestic Calendar of State Papers, and a remark in a document in the papers of secretary of state Sir John Coke, we know little about the formation of the company and the letters of marque received by David Kirke, notwithstanding a handful of red herrings in the footnotes of certain historians. It does not appear to have helped certain other historians that March 25th begins the new year in the old calendar. Warrants for Issuing Letters of Marque or Commissions to Take Pirates (17 December 1627), CSP Domestic: Charles I (1628-29) (London, 1859), 303; CM 1: 375.

${ }^{55} C M 1: 374-6$.

${ }^{56}$ OC 5: 1159-60.

${ }^{57}$ OC 5: 1161-2.

${ }^{58}$ OC 5: 1162-3.

${ }^{59} C M 1: 375$. The number of Basque and French fishing ships taken by the Kirkes, as given by Champlain, is nineteen, but fewer appear to have been retained in the possession of the Kirkes, perhaps some figure between four and eight. OC 5: 1274-5.

${ }^{60}$ For Edward Lord Barrett of Newburgh, the English nobleman of Scotland and one-time ambassador to France, the St. Lawrence trade now presented an opportunity to 'unite both kingdoms [of Scotland and England] in a work that is large enough to spread the glory of it over both'. Propositions of Accommodation for the Settling of the Trade and Plantation in Canada or New France (1628), CM 1: 376-7; The State of the Business of Canada or New France (1628), $C M$ 1: 376. Available evidence of this project is scant, but it seems that an incorporation of such diverse interests, in the end, proved too difficult to make work. The 'Anglo-Scotch Company' was only ever an informal union of early 1629, when the Kirkes and Sir William Alexander the younger sent separate expeditions, with their separate backers, for New France. CSP Colonial (America and West Indies) 1: 96.

${ }^{61}$ La Rochelle had been where a largely Calvinistic merchant community looked to Africa, America, and the Indies for new trading opportunities on the eve of its expulsion. See Robbins, City on the Ocean Sea. For the argument that the Catholic verve of New France and the deprotestantisation of La Rochelle were related developments, see Bosher, "The Political and Religious Origins of La Rochelle's Primacy." For context see Scott, The State in Early Modern France, 36-70; Parrott, Richelieu's Army.

${ }^{62}$ Deposition before the Admiralty court Nov. 17 1629, CSP Colonial (America and West Indies) 1: 102-4.

${ }^{63}$ OC 5: 1223.

${ }^{64}$ OC 5: 1224.

65 Articles Demanded by Champlain (19 July 1629), NAUK CO 1/5, 55-8; Collection Concernant la Capitulation de Québec (1629), LAC R9945-0-1-F; OC 5: 1230-1.

${ }^{66}$ Treaty between Great Britain and France signed at Susa and London (24 April 1629), Davenport, European Treaties, 1: 303-4. For drafts and commentary, consult the collected letters at AD CPA vol. 43 (Mfm 6372): 29-102.

${ }^{67}$ For the context and a copy of the Treaty concluded between Great Britain and France at St.Germaine-en-Laye (19/29 March 1632), see Davenport, Treaties, 1: 315-23. See also, above, footnote nine.

${ }^{68}$ See Mathiasen, "Some Problems of Admiralty Jurisdiction in the 17th Century."; Steckley, "Merchants and the Admiralty Court," esp. 141-8. 
${ }^{69}$ Depositions of Samuel Champlain, Eustacie Boulle, and Nicholas Blundell (9 November 1629), NAUK CO 1/5/34, 89-92; CSP Colonial (America and West Indies) 1: 102-3.

${ }^{70}$ Grievances of the French General and Commissary General (November 1629), CSP Colonial (America and West Indies) 1: 102.

${ }^{71}$ Depositions of Kirke Brothers (17 November 1629), NAUK CO 1/5/37, 95; CSP Colonial (America and West Indies) 1: 103-4.

${ }^{72}$ Memorial of the French Ambassador to King Charles (January[?] 1630), CSP Colonial (America and West Indies) 1: 107.

${ }_{73}$ Declaration of Charles in response to Articles of Peace (24 April 1629), AD CPA 43: 54.

${ }^{74}$ In either case, it was the working out of a peace with Spain that occupied the English king's mind at this period, as it did, to a large degree, Châteuneuf's.

75 Answeares to give severall Memorialls presented by the French Ambassador (1 February 1630), NAUK CO 1/5/2, 121-2.

${ }^{76}$ Commission to Sir Humphrey May, Sir John Coke, Sir Julius Cæsar, and Sir Hen. Marten (5 March 1630), NAUK CO 1/5/2, 135.

${ }^{77}$ It does not appear that this was the result of a formal suit before the London Mayor's Court, even if this court would seem to have enjoyed jurisdiction because the furs in question, as well as the competing claimants, were situated in London. Visiting merchants had traditionally made use of this court, which for centuries ruled according to the customs of lex mercatoria (called in England the 'Law Merchant'), but generally it was used for the recovery of small debts of less than $£ 5$; in this case, the value of the disputed furs was over a thousand pounds. For the medieval history of the Mayor's Court, see Thomas, Calendar of Early Mayor's Court Rolls.

${ }_{78}^{78}$ Order of the Privy Council (2 April 1630), NAUK CO 1/5/2, 169.

${ }^{79}$ CSP Colonial (America and West Indies) 1: 112. Guillaume de Caën's departure was hastened by ongoing suits with the Compagnies de Montmorency, de Rouen et Saint-Malo, and de Nouvelle-France, at the centre of which was '1'affair Langlois'. For this, see Helen Dewar, "Y establir nostre auctorité,", 207-49; Le Blant, "Les Débuts Difficiles de la Compagnie de la Nouvelle-France."

${ }^{80}$ James Cambell, Lord Mayor of London, to the Privy Council (28 April 1630), NAUK CO 1/5/87, 183.

${ }^{81}$ Affidavit of Josua Mainet, NAUK CO 1/5/87, 185 (enclosure); CSP Colonial (America and West Indies) 1: 114.

${ }^{82}$ Warrant to the Lord Mayor and Sheriffs of London (18 May 1630), NAUK CO 1/5, 79; CSP Colonial (America and West Indies) 1: 115-116. This comes from the Admiralty.

${ }^{83}$ Order of the Privy Council for the Attorney General to proceed against Thos. Fittz in the Star Chamber for 'great contempt and affront of all authority and justice' (16 June 1630), NAUK CO 1/5/79, 169; CSP Colonial (America and West Indies) 1: 117.

${ }^{84}$ Records of Privy Council (9 July 1630, 14 July 1630), CSP Colonial (America and West Indies) 1: 118.

${ }^{85}$ Biggar, Early Trading Companies, 161-2.

${ }^{86}$ It is unclear exactly when between late 1629 and early 1631 Kirke's furs were confiscated by Admiralty.

${ }^{87}$ Examination of Capt. David Kirke before Sir Hen. Marten. (27[?] May 1631) NAUK CO $1 / 6,15$. See also Brief declaration of the number of beaver skins brought by Capt. David Kirke (2 May 1631) NAUK CO 1/6, 12; CSP Colonial (America and West Indies) 1: 129.

${ }^{88}$ Biggar, Early Trading Companies, 162-3.

${ }^{89}$ See, for example, the List of the 'Marchandises de Traicté' sent to Quebec, found in the Mary Fortune of London, and taken at Tadousac (1632[?]), NAUK CO 1/6, 50. See also the inventory of Champlain, at NAUK CO 1/6, 49, and compare NAUK CO 1/6, 38. 
${ }^{90}$ Answer of the Adventurers of Canada to the articles contained in a letter from Sir Isaac Wake, the King's Ambassador in France (9 April 1632), NAUK CO 1/6/53, 133-4.

${ }^{91}$ Objections [in Sec. Lord Cottington's hand] to certain arrangements, whereby the King is obliged to pay 14,3301. for supposed debts to Du Cane from the Canada merchants (1632), NAUK CO 1/6/45, 118. Charles I appears to have always been prepared to guarantee the return of the St. Laurence posts taken by the Kirkes, but only for the right concessions in return. Foremost here was the outstanding balance due to England for the dowry of Henrietta Maria. The evacuation of Nova Scotia, by contrast, was ordered more reluctantly in February of 1631, in spite of the last-ditch attempts of Scottish proprietors and investors to preserve their threatened interests. For this, see the papers collected at BL Egerton 2395, esp. 19-25; and the Discourse Concerning his Majesty's rights and titles to the Port Royall and whole [of] Canada (9 September 1630), NAUK CO 1/5/2, 223-5. The Compagnie de la Nouvelle-France, albeit not without first overcoming a few impediments left by residual proprietary interests, would eventually take control of Port Royal. For context, see Dewar, "YY establir nostre auctorité,", 207-47. See also Reid's, Acadia, Maine and New Scotland.

${ }^{92}$ Protestion faite par le capitaine Emery de Caën (19 July 1632), LAC R12297-2-8-F; Trudel, "Caën, Guillaume de."

${ }^{93}$ For French admiralty courts, see Mousnier, Institutions of France II, esp. 296-9; James, Navy and Government, 11-76. For a recent analysis of the operation of French admiralty courts in relation to a dispute with the Portuguese over prize, see Trivellato, "Amphibious Power."”

${ }^{94}$ ANF Amirauté de France, sous-série z1d/105.

${ }^{95}$ Demands of the Canada Adventureres from Wil. De Caen of Dieppe (17 June 1633), NAUK CO 1/6, 75; Petition of George Kirk, David Kirk, William Barkley, Joshua Gallard, and others (1633), CMS 2: 42; Sir David Kirke, Will. Berkeley, and John Kirke, to Sec. Coke (22 January 1636) NAUK CO 1/9, 1.

96 This observation comes with the important disclaimer that the term 'private international law' would not be coined until the early nineteenth century, and it would not be until the second half of that century that it came to refer to those conflicts of law and jurisdiction which affect private interests. By way of introduction, consult Westlake, A Treatise on Private International Law; Dicey, A Digest of the Law of England; Argúas, "The Montevideo Treaties of 1889 and 1940." 